\title{
Autofluorescence of NADH is a new biomarker for sorting and characterizing cancer stem cells in human glioma
}

Ye Yuan, Zexuan Yan, Jingya Miao, Ruili Cai, Mengsi Zhang, Yanxia Wang, Lihong Wang, Weiqi Dang, Di Wang, Dongfang Xiang, Yan Wang, Peng Zhang, Youhong Cui ${ }^{*}$ Xiuwu Bian ${ }^{*}$ and Qinghua Ma*

\begin{abstract}
Background: The existing cell surface markers used for sorting glioma stem cells (GSCs) have obvious limitations, such as vulnerability to the enzymatic digestion and time-consuming labeling procedure. Reduced nicotinamide adenine dinucleotide (NADH) as a cellular metabolite with property of autofluorescence has the potential to be used as a new biomarker for sorting GSCs.

Methods: A method for sorting GSCs was established according to the properties of the autofluorescence of $\mathrm{NADH}$. Then, the $\mathrm{NADH}^{\text {high }}$ and $\mathrm{NADH}^{\text {low }}$ subpopulations were sorted. The stem-like properties of the subpopulations were evaluated by qRT-PCR, western blot analyses, limiting dilution assay, cell viability assay, bioluminescence imaging, and immunofluorescence analysis in vitro and in vivo. The relationship between $\mathrm{CD}_{133^{+}} /$ $\mathrm{CD}_{15}{ }^{+}$cells and $\mathrm{NADH}^{\text {high }}$ subpopulation was also assessed.

Results: $\mathrm{NADH}^{\text {high }}$ cells expressed higher stem-related genes, formed more tumor spheres, and harbored stronger pluripotency in vitro and higher tumorigenicity in vivo, compared to $\mathrm{NADH}^{\text {low }}$ subpopulation. $\mathrm{NADH}^{\text {high }}$ glioma cells had the similar stemness with $\mathrm{CD}_{133^{+}}$or $\mathrm{CD} 15^{+} \mathrm{GSC}$, but the three subpopulations less overlaid each other. Also, $\mathrm{NADH}^{\text {high }}$ glioma cells were more invasive and more resistant to chemotherapeutic drug temozolomide (TMZ) than $\mathrm{NADH}^{\text {low }}$ cells. In addition, the autofluorescence of NADH might be an appropriate marker to sort cancer stem cells (CSCS) in other cancer types, such as breast and colon cancer.
\end{abstract}

Conclusion: Our findings demonstrate that intracellular autofluorescence of NADH is a non-labeling, sensitive maker for isolating GSCs, even for other CSCs.

Keywords: Glioma stem cells, Autofluorescence, NADH, FACS, Biomarker

\section{Background}

Glioma stem cells (GSCs) are believed to be responsible for tumor initiation, progression, chemo- and radioresistance, and recurrence of gliomas [1-4]. The identification and isolation of GSCs are crucial for a better understanding of their properties and developing GSCtargeting therapies. GSCs are usually identified and isolated from primary tumors or glioma cell lines by fluorescence-activated cell sorting (FACS) based on the

\footnotetext{
* Correspondence: cuiyouhongx@yahoo.com; bianxiuwu@263.net; qinghuama1982@163.com

Institute of Pathology and Southwest Cancer Center, Key Laboratory of the Ministry of Education, Southwest Hospital, Third Military Medical University (Army Medical University), Chongqing 400038, China
}

cell surface makers, such as CD133 and CD15. Early studies reported that only $100 \mathrm{CD} 133$-positive cells of glioma could produce a phenocopy of parent tumor in NOD-SCID mice, whereas $10^{5}$ CD133-negative cells could not $[1,5]$. CD15 has also been considered as another reliable surface marker for isolating GSCs [6]. However, recent studies indicated that CD133- or CD15-negative glioma cells also possessed some GSC characteristics [6-8]. It is unclear whether partial CD133/CD15-negative cells have the properties of CSCs per se or partial CD133/CD15-negative GSCs are derived from CD133/CD15-positive subpopulation missing the markers by enzymatic digestion $[9,10]$. In addition, the antibodies of CD133/CD15 are expensive and the

(c) The Author(s). 2019 Open Access This article is distributed under the terms of the Creative Commons Attribution 4.0 International License (http://creativecommons.org/licenses/by/4.0/), which permits unrestricted use, distribution, and 
labeling process is time-consuming. Therefore, it is necessary to find alternative strategies, which are more specific, simple, and economic for the isolation of GSCs.

Energy metabolism is involved in the self-renewal, reprogramming, and differentiation of regular stem cells and cancer stem cells (CSCs) $[11,12]$. Reduced nicotinamide adenine dinucleotide (NADH) is a key carrier of electrons in cellular energy metabolism. It possesses a property of autofluorescence with an excitation wavelength at $340 \pm 30 \mathrm{~nm}$ and an emission wavelength within the $460 \pm 50 \mathrm{~nm}$ range [13, 14], and has been used as an important intracellular autofluorescence component to non-invasively monitor and analyze metabolic activity of living cells and tissues [15, 16]. Recently, $\mathrm{NADH}$ fluorescence intensity and fluorescence lifetime of bound and free NADH have been used to distinguish stem cells from their differentiated progeny [17-19]. Besides, NADH has been used to screen or monitor GSC metabolic state by using fluorescence lifetime microscopy (FLIM) [20]. However, the usability of NADH autofluorescence in the isolation and purification of GSCs by FACS has not been evaluated.

In the present study, we applied the autofluorescence of NADH as a non-labeling marker to isolate GSCs by FACS. Compared to NADH ${ }^{\text {low }}$ subpopulation, NADHhigh subpopulation exhibited higher stem-like properties, including abilities of self-renewal, multilineage differentiation, and tumorigenesis, as well as higher invasive ability and resistance to chemotherapeutic temozolomide (TMZ). Besides, NADH ${ }^{\text {high }}$ as a biomarker could be used to isolate breast and colon CSCs. Therefore, NADH is a suitable biomarker for the isolation of GSCs or other CSCs.

\section{Materials and methods}

\section{Human glioma specimens and the preparation of single} cell suspension

A total of 13 fresh surgical glioma specimens were collected from patients enrolled in the Southwest Hospital, Third Military Medical University, Chongqing, China, after signing an informed consent from patients or their guardian. All patients had not received chemoradiotherapy before surgery. The histopathological grading was in accordance with the World Health Organization (WHO) classification (2016). The clinicopathologic information of these patients is summarized in Additional file 1: Table S1. This study was approved by the Ethics Committee of Southwest Hospital.

To prepare the single cell suspension, fresh surgical glioma tissues were collected and cut into small pieces immediately, and then, glioma cells were isolated using the Papain Dissociation System (Worthington Biochemical, Lakewood, NJ, USA) as previously reported [21, 22] and suspended in PBS at $1-5 \times 10^{6}$ cells $/ \mathrm{mL}$.

\section{Cell lines and culture}

Glioma cell lines (T98G, LN229), breast cancer cell line (MDA-MB-231), and colon cell line (HT-29) were purchased from ATCC (VA, USA). Primary glioma cells GBM1 and GBM2 were respectively isolated from two human glioma surgical specimens in our laboratory [23, 24]. All the cell lines were maintained in DMEM (HyClone, USA) supplemented with $10 \%$ fetal bovine serum (FBS) (HyClone, USA). The medium for tumorsphere culture was composed of F12 medium containing $20 \mu \mathrm{L} / \mathrm{mL}$ B27 supplement (Gibco, USA), $20 \mathrm{ng} / \mathrm{mL}$ basic fibroblast growth factor (bFGF), and $20 \mathrm{ng} / \mathrm{mL}$ epidermal growth factor (EGF) (both from PeproTech, USA) without serum. All the cells were cultured at $37^{\circ} \mathrm{C}$ in $5 \% \mathrm{CO}_{2}$ and $100 \%$ humidity.

\section{FACS analysis and cell sorting}

The cultured glioma cells were digested by trypsin or accutase and resuspended with PBS. The fresh glioma specimens were transferred to laboratory on ice in half hour after surgery, then washed and enzymatically dissociated into single cells and resuspended in PBS. The staining procedures for $\mathrm{CD} 133$ and $\mathrm{CD} 15$ markers were performed as previously described [6, 8]. The labeling antibodies were anti-CD133-APC antibody (Clone REA816; Miltenyi Biotec, Germany) and anti-CD15FITC antibody (Biolegend, USA) with REA Control (S)APC (Miltenyi Biotec, Germany) and FITC Mouse IgM (Biolegend, USA) as controls, respectively.

The FACS analysis and cell sorting were performed on BD FACS Aria II cytometer (USA) or Beckman moflo XDP (USA). For analyzing and sorting with NADH autofluorescence intensity as a marker, an excitation wavelength of $375 \mathrm{~nm}$ or $355 \mathrm{~nm}$ and an emission wavelength of 450/50BP filter were used. For analyzing and sorting with CD133 and CD15 as markers, labeled cells were analyzed and sorted with corresponding excitation and emission wavelengths of the fluorochrome. All data were analyzed with BD FACSDiva software version 8 or Beckman moflo XDP submmit 5.2.

\section{Limiting dilution assay}

Limiting dilution assay was performed as previously described [24]. Briefly, serial twofold dilutions (from 40 to 0 cells) of different glioma, breast cancer, and colon cells were seeded into ultra-low adhesion 96-well plates (10 wells per dilution) (Costar, USA) and cultured in tumorsphere medium. After incubation for 2 weeks, wells without spheres $(\log 2, Y$-axis) were counted and plotted against the number of cells plated per well $(X$-axis) to calculate the sphere formation efficiency.

\section{RNA preparation and qRT-PCR}

Total RNAs from sorted cells by FACS were extracted with RNA extracting Kit (Fastagen, China) according to the 


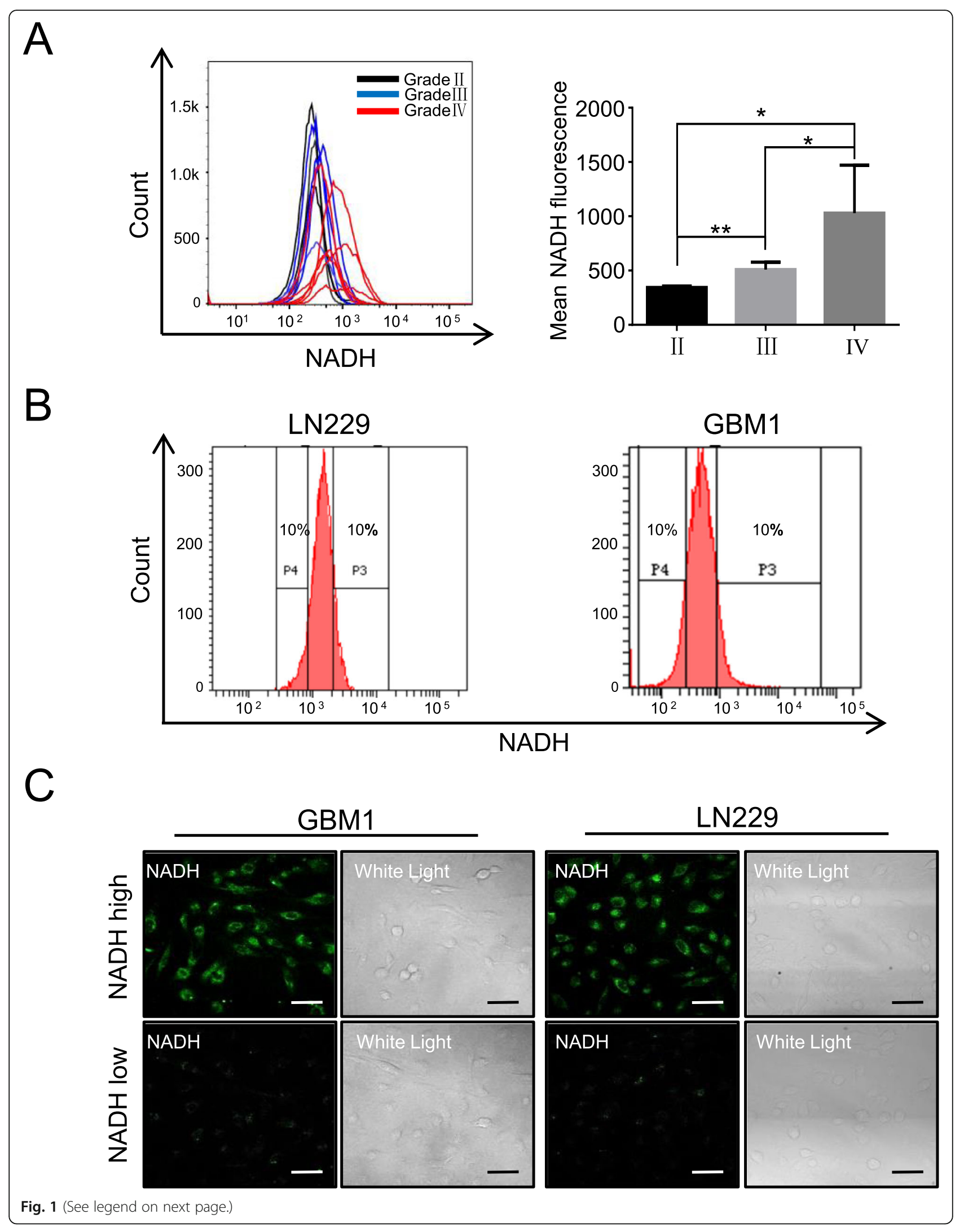


(See figure on previous page.)

Fig. $1 \mathrm{NADH} \mathrm{H}^{\text {high }}$ and $\mathrm{NADH}{ }^{\text {low }}$ glioma cell subpopulations can be sorted according to their intensity of NADH autofluorescence. a The intensity of NADH autofluorescence increased with WHO grades in primary glioma cells. Also, the intensity of NADH autofluorescence in patients within same grade II $(n=4)$ or III $(n=3)$ was similar, but major difference in grade IV $(n=6)$ patients was observed. b Glioma cells with the highest top $10 \%$ and lowest bottom $10 \%$ intensity of $\mathrm{NADH}$ autofluorescence were defined as $\mathrm{NADH}^{\text {high }}$ and NADH ${ }^{\text {low }}$, respectively. c The intensity of NADH autofluorescence in sorted $\mathrm{NADH}^{\text {high }}$ and $\mathrm{NADH}^{\text {low }}$ glioma cells was verified by confocal microscopy. All data are presented as the means \pm SD. ${ }^{*} p<0.05,{ }^{* *} p<0.01$ ( $n=3$ independent experiments)

manufacturer's instructions. One microgram of total RNA was reverse transcribed with the Reverse Transcription Kit (Takara, Dalian, China). Quantitative real-time PCR was carried out using the SYBR PrimeScript PCR kit II (TaKaRa, Japan). The level of $\beta$-tubulin mRNA was used as the internal control. The primers used in this study are listed in Additional file 1: Table S2.

\section{Cell viability assay and IC50 evaluation}

Different subpopulations of GBM1 and LN229 cells were seeded in 96-well plates at $2 \times 10^{3}$ cells/well and treated with TMZ at the indicated concentrations for $48 \mathrm{~h}$. The viability of glioma cells was measured by using a Cell Counting Kit-8 (Beyotime, China) according to the manufacturer's instructions. The OD values at $450 \mathrm{~nm}$ were recorded by fluoroanalyzer (Floskan Ascent, USA).

\section{Immunofluorescence analysis}

For induction of differentiation, NADH ${ }^{\text {high }}$ cells were cultured in DMEM with 10\% FBS for 7 days. The NADH ${ }^{\text {high }}$ cells cultured in same conditions within $6 \mathrm{~h}$ were used as controls. Both differentiated and control cells were fixed in $4 \%$ paraformaldehyde for $30 \mathrm{~min}$, washed three times with PBS at room temperature, and incubated with blocking buffer containing $10 \%$ normal goat serum and $0.3 \%$ Triton. The samples were incubated with primary antibodies anti-Sox2 (\#3579, 1:400, CST), anti-Nestin (\#33475, 1:400, CST), and anti-GFAP (\#12389, 1:400, CST) overnight at $4{ }^{\circ} \mathrm{C}$. Hoechst 33342 was used to counterstain the cell nuclei. After washing with PBS, the samples were mounted with Immuno-Mount ${ }^{\mathrm{Tm}}$ (Thermo Scientific, USA) and then examined on a LEICA TCS-SP5 confocal microscope $(\times 63$ objective).

\section{Xenograft in NOD-SCID mice and bioluminescence imaging}

The animal study was performed in accordance with the protocol approved by the Institutional Animal Care and Use Committee of Southwest Hospital, Third Military Medical University (TMMU). NOD/SCID female mice ( 5 weeks old) were purchased from the Laboratory Animal Center of TMMU. Different treated GBM cells were washed and resuspended in PBS and mixed with Matrigel (1:1, BD Biosciences), then subcutaneously injected into NOD/SCID mice at $4 \times 10^{3}, 4 \times 10^{4}$, and $4 \times 10^{5}$ cells $(100 \mu \mathrm{L} / \mathrm{site})$ with the left flank as the test group and right flank as the control group. Tumor growth was monitored by bioluminescence imaging using In Vivo Imaging System (IVIS) Spectrum (Perkin Elmer, USA) and Living Image Software for IVIS (Perkin Elmer). At the end of 6 weeks after the injection, the mice were killed. Xenograft tumors were removed and weighted.

\section{Western blotting}

Western blotting was performed as previously described [25]. The primary antibodies used in western blot were anti-Sox2 (\#3579, 1:1000, CST), anti-CD133 (\#64326, 1: 1000, CST), anti-Nanog (\#8822, 1:1000, CST, USA), and anti- $\beta$-tubulin (\#2128, 1:10000, CST).

\section{Transwell invasion analysis}

Glioma cells were seeded into the upper chambers (Millipore, $8.0 \mu \mathrm{m}, 24$ well) that were coated with $15 \mu \mathrm{L} /$ well of Matrigel in advance (Corning, USA) at the density of $3 \times 10^{4}$ cells/well in $200 \mu \mathrm{L}$ of serum-free DMEM, and then, the upper chambers were placed in a 24-well plate added with $600 \mu \mathrm{L} /$ well DMEM supplemented with $10 \%$ FBS. After incubation for $24 \mathrm{~h}$, the cells were fixed with $4 \%$ paraformaldehyde followed by crystal violet staining. Non-invading cells were removed with a cotton swab, and the images of stained cells were collected by microscope (Olympus, Japan).

\section{Statistical analysis}

All experiments were performed at least three times. Statistical analysis was performed by using SPSS statistical software (SPSS16.0, Chicago, CA, USA) and GraphPad Prism 6 software (GraphPad, La Jolla, CA, USA). The unpaired two-group comparison and multiple comparisons were made with Student's $t$ test or one-way ANOVA, respectively. Data were presented as the mean \pm SD. Statistical significance was set at $* p<0.05$, $* p<0.01$, and $* * * 0<0.001$.

\section{Results \\ $\mathrm{NADH}^{\text {high }}$ and $\mathrm{NADH}^{\text {low }}$ subpopulations can be sorted from glioma cells by FACS in vitro}

By using flow cytometry, we firstly examined the autofluorescence intensity of NADH in 13 fresh glioma tissues, including 4 WHO grade II, 3 grade III, and 6 grade IV. The autofluorescence intensity of NADH was increased with WHO grades (grade IV $>$ grade III $>$ grade 


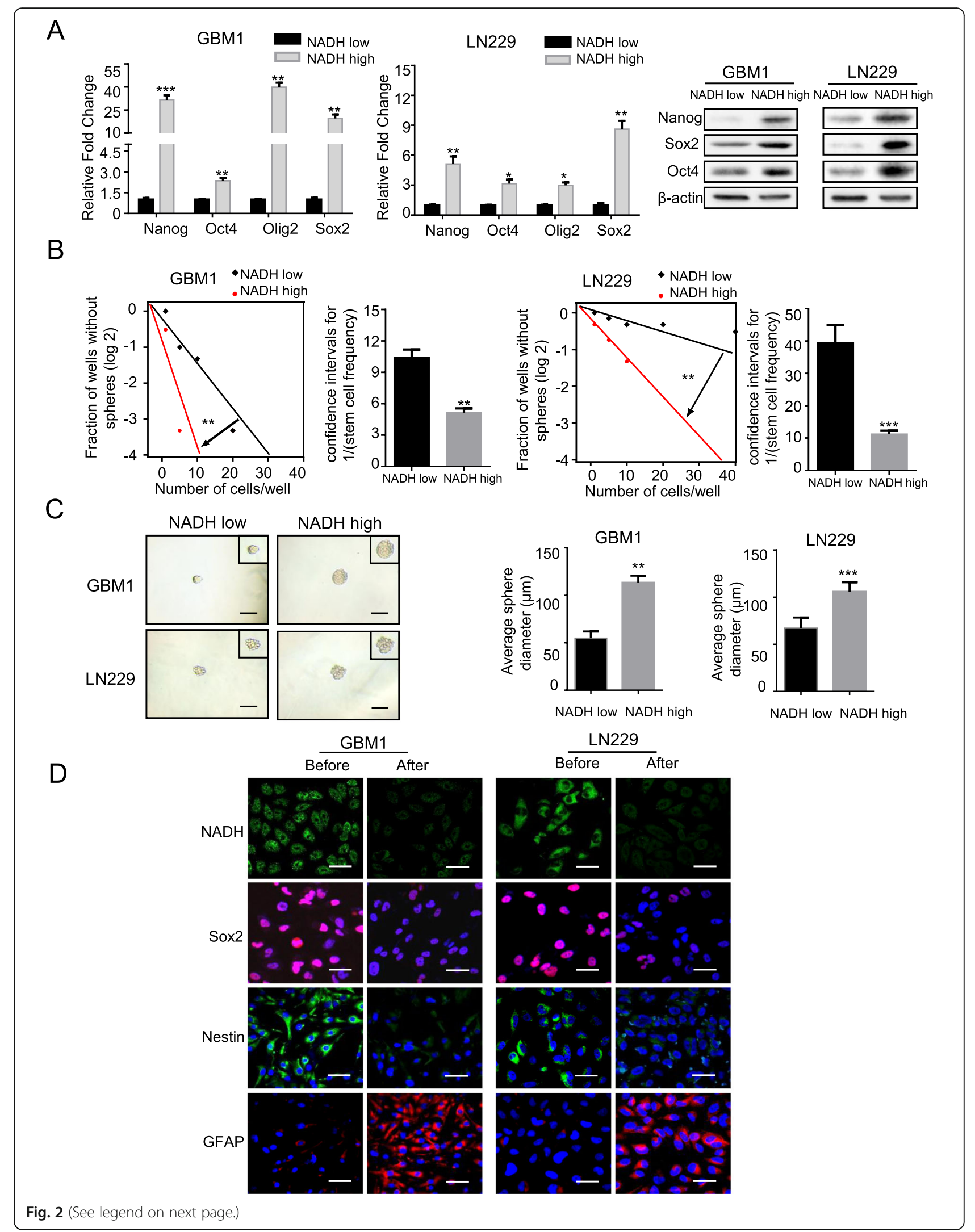


(See figure on previous page.)

Fig. $2 \mathrm{NADH}^{\text {high }}$ glioma cells exhibit characteristics of GSCs in vitro. a qRT-RCR and western blotting analyses showed higher expression levels of stem-related genes in NADH ${ }^{\text {high }}$ cells than in NADH low cells in GBM1 and LN229 cell lines. b, c Limiting dilution assays showed higher tumorsphere formation rates and longer average diameter of tumorsphere in NADH ${ }^{\text {high }}$ cells compared to NADH ${ }^{\text {low }}$ cells in GBM1 and LN229 cell lines. d Cultured in medium supplemented with $10 \%$ FBS for 7 days, $\mathrm{NADH}^{\text {high }}$ cells markedly reduced the autofluorescence of NADH and the expression of neural stem/progenitor markers Sox2 and Nestin, but re-expressed high astroglial marker GFAP. Scale bar $=50 \mu \mathrm{m}$. All data are presented as the means \pm SD. ${ }^{*} p<0.05,{ }^{* *} p<0.01,{ }^{* *} p<0.001$ ( $n=3$ independent experiments)

II); in low-grade gliomas (grades II and III), the autofluorescence intensity of NADH was similar between the samples, but large difference between samples was observed in grade IV (Fig. 1a, Additional file 1: Figure S1). According to previous reports [26, 27], we defined the highest top $10 \%$ intensity as high autofluorescence of NADH $\left(\mathrm{NADH}^{\text {high }}\right)$ and defined the lowest bottom 10\% intensity as low autofluorescence of NADH $\left(\mathrm{NADH}^{\text {low }}\right)$. Accordingly, we sorted the subpopulations with top $10 \%$ and bottom $10 \%$ intensity of NADH autofluorescence from GBM1 and LN229 cells (Fig. 1b). To confirm the autofluorescence intensity of NADH in both NADH ${ }^{\text {high }}$ and $\mathrm{NADH}^{\text {low }}$ subpopulations, we examined the intensity of NADH autofluorescence with confocal analysis. The cells with top $10 \%$ intensity of NADH showed strong autofluorescence intensity, while the cells with bottom $10 \%$ intensity of NADH had weak fluorescence signal (Fig. 1c). These results indicate that $\mathrm{NADH}^{\text {high }}$ and $\mathrm{NADH}^{\text {low }}$ subsets existed in glioma cells and could be promptly isolated by FACS.

\section{NADH ${ }^{\text {high }}$ glioma cells exhibit GSC traits in vitro}

To evaluate the stem-related properties of $\mathrm{NADH}^{\text {high }}$ and $\mathrm{NADH}^{\text {low }}$ glioma cells in vitro, we first compared the expression of stem-related genes in both subpopulations. Compared to $\mathrm{NADH}^{\text {low }}$ subpopulation, $\mathrm{NADH}^{\text {high }}$ glioma cells highly expressed stem-related genes Nanog, Oct-4, Oligo2, and Sox2 at both mRNA and protein levels in GBM1 and LN229 cells (Fig. 2a). Then, the tumorsphere formation of $\mathrm{NADH}^{\text {high }}$ and $\mathrm{NADH}^{\text {low }}$ cells was measured through a limiting dilution analysis. In comparison with $\mathrm{NADH}^{\text {low }}$ glioma cells, $\mathrm{NADH}^{\text {high }}$ cells showed higher rate of tumorsphere formation in both GBM1 and LN229 cells ( $p<0.01$ for both) (Fig. 2b). Moreover, the average diameter of the tumorspheres derived from NADH ${ }^{\text {high }}$ cells was about twice as much as that derived from NADH ${ }^{\text {low }}$ cells in GBM1 and LN229 cells ( $p<0.01$ for both) (Fig. 2c).

Previous studies showed that GSCs harbored multipotency to differentiate into neurons, astrocytes, and oligodendrocytes, and stem cell markers disappeared with the differentiation $[28,29]$. Hence, we evaluated whether the $\mathrm{NADH}^{\text {high }}$ subpopulation had multiple differentiation potential by a differentiation assay. As expected, the differentiated NADH ${ }^{\text {high }}$ cells almost lost not only autofluorescence of NADH but also neural stem/progenitor markers Sox2 and Nestin and re-expressed astroglial marker GFAP (Fig. 2d). Thus, these data strongly indicate that $\mathrm{NADH}^{\text {high }}$ glioma cells have the characteristics of GSCs in vitro.

\section{$\mathrm{NADH}^{\text {high }}$ glioma cells show high tumorigenicity in vivo}

The stem-related properties of $\mathrm{NADH}^{\text {high }}$ and $\mathrm{NADH}^{\text {low }}$ glioma cells in vivo were further evaluated by xenograft experiment in NOD-SCID mice. Bioluminescent analyses showed that the tumor size derived from NADHhigh subpopulation was significantly larger than that derived from $\mathrm{NADH}^{\text {low }}$ subpopulation in LN229 cells at 28 days after implantation (Fig. 3a). As shown in Fig. 3b and Additional file 1: Table S3, the tumor incidence rate of NADH ${ }^{\text {high }}$ cells was higher than that of NADH ${ }^{\text {low }}$ cells. The weight of tumors derived from NADH ${ }^{\text {high }}$ cells was heavier than that derived from $\mathrm{NADH}^{\text {low }}$ cells (Fig. 3b). H\&E staining confirmed the glioma origin of tumors, and IHC showed that the tumors derived from $\mathrm{NADH}^{\text {high }}$ cells exhibited higher Ki-67 and Sox 2 expression than those derived from $\mathrm{NADH}^{\text {low }}$ cells (Fig. 3c). These results indicate that NADH ${ }^{\text {high }}$ glioma cells have high tumorigenicity in vivo.

\section{NADH ${ }^{\text {high }}$ glioma subpopulation possesses similar stem- like properties with $\mathrm{CD} 133^{+}$or $\mathrm{CD} 15^{+}$cells, but only partially overlaps with them}

Since CD133 and CD15 are usually used as makers to enrich GSCs by FACS, the relationship between NADHhigh, $\mathrm{CD} 133^{+}$, and $\mathrm{CD} 15^{+}$subpopulations was assessed. We first measured the proportions of $\mathrm{CD}_{133^{+}}$and CD15 cells in GBM1, GBM2, T98G, and LN229 cells and found that the percentages were $0.73 \pm 0.04 \%$, $0.47 \pm 0.04 \%, 1.37 \pm 0.22 \%$, and $0.53 \pm 0.04 \%$, and $0.50 \pm$ $0.07 \%, 0.1 \%, 4.77 \pm 0.24 \%$, and $0.13 \pm 0.09 \%$, respectively (Additional file 1: Figure S2 and Figure S3, Table 1), which was consistent with previous reports [30-32]. We then compared the proportions of $\mathrm{CD}_{133^{+}}$and $\mathrm{CD}_{15} 5^{+}$cells in $\mathrm{NADH}^{\text {high }}$ and $\mathrm{NADH}^{\text {low }}$ subpopulations in those glioma cell lines. The percentages of CD133 ${ }^{+}$ cells were elevated about two times in $\mathrm{NADH}^{\text {high }}$ subpopulation, but no obvious change in $\mathrm{NADH}^{\text {low }}$ subpopulations of those cell lines (Additional file 1: Figure S2, Additional file 1: Table S1). The proportion changes of $\mathrm{CD}_{1} 5^{+}$cells in $\mathrm{NADH}^{\text {high }}$ and $\mathrm{NADH}^{\text {low }}$ subpopulations were similar to those of $\mathrm{CD}_{133^{+}}$cells (Additional file 1: 


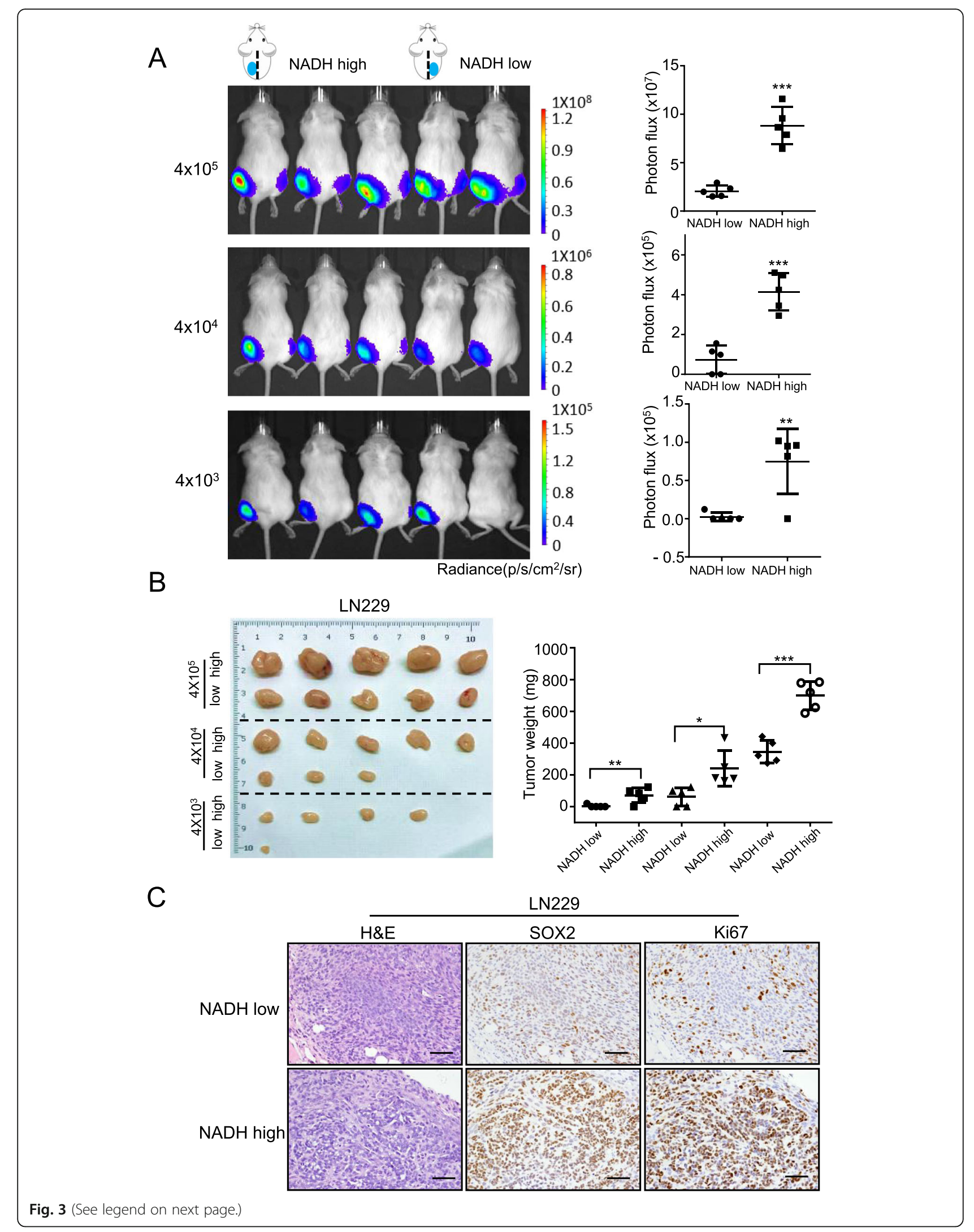


(See figure on previous page.)

Fig. $3 \mathrm{NADH}^{\text {high }}$ glioma cells exhibit characteristics of cancer stem cells in vivo. a Bioluminescent images and quantification showed that the total flux of the tumors derived from NADH high LN229 cells (left flank) was extremely higher than that of the tumors derived from NADH $H^{\text {low }}$ LN229 cells (right flank) at 28 days after subcutaneous implantation in NOD/SCID mice. Also, the total photon flux of the tumors was increased with implanted cell number. Signal intensity is represented as $\mathrm{p} / \mathrm{s} / \mathrm{cm}^{2} / \mathrm{sr}$. b The images of xenograft tumors showed that NADH high $L N 229$ cells had higher rate of tumor formation than $\mathrm{NADH}^{\text {low }}$ cells (left panel). Weight statistical diagram showed that the weight of NADH ${ }^{\text {high }}$ LN229 cellderived tumors was heavier than that of NADH ${ }^{\text {low }}$ LN229 cell-derived tumors (right panel). $\mathbf{c}$ H\&E staining confirmed the glioma origin of the xenograft tumors, and IHC staining showed that $\mathrm{NADH}^{\text {high }} \mathrm{LN} 229$ cell-derived tumors expressed higher expression of Sox2 and Ki67 than $\mathrm{NADH}^{\text {low }}$ cells. Scale bar $=50 \mu \mathrm{m}$. All data are presented as the means \pm SD. ${ }^{*} p<0.05,{ }^{* *} p<0.01,{ }^{* * *} p<0.001(n=3$ independent experiments)

Figure S3, Additional file 1: Table S1). The proportion of $\mathrm{NADH}^{\text {high }}$ cells in $\mathrm{CD}_{133^{+}}$and $\mathrm{CD} 15^{+}$subpopulations was also analyzed. The percentages of NADH ${ }^{\text {high }}$ cells ranged from 20.1 to $63.7 \%$ in $\mathrm{CD} 133^{+}$subpopulation and from 10 to $86.2 \%$ in $\mathrm{CD}_{15}{ }^{+}$subpopulation in the four cell lines (Additional file 1: Figure S4). These results suggest that $\mathrm{NADH}^{\text {high }}$ subpopulation is only partially overlapped with $\mathrm{CD} 133^{+}$or $\mathrm{CD}_{15}{ }^{+}$subpopulation.

To further illustrate the relationship among NADHhigh, $\mathrm{CD}_{133^{+}}$, and $\mathrm{CD} 15^{+}$subpopulations, we compared the stem-like properties of subpopulations with different combination of the expression status of $\mathrm{NADH}$ and $\mathrm{CD} 133 / \mathrm{CD} 15$, including $\mathrm{NADH}^{\text {high }} / \mathrm{CD} 133^{+}, \mathrm{NADH}^{\text {high }} /$ $\mathrm{CD}_{133^{-}}, \mathrm{NADH}^{\text {low }} / \mathrm{CD}_{133^{+}}, \mathrm{NADH}^{\text {low }} / \mathrm{CD} 133^{-}, \mathrm{NADH}-$ high $/ \mathrm{CD} 15^{+}, \mathrm{NADH}^{\text {high }} / \mathrm{CD} 15^{-}, \mathrm{NADH}^{\text {low }} / \mathrm{CD} 15^{+}$, and $\mathrm{NADH}^{\text {low }} / \mathrm{CD} 15^{-}$. $\mathrm{NADH}^{\text {high }} / \mathrm{CD} 133^{+}$subpopulation showed the highest expression of stem-related genes Nanog, Oct4, Oligo2, and Sox2, whereas $\mathrm{NADH}^{\text {low }}$ / $\mathrm{CD}_{133^{-}}$subpopulation had the lowest expression of those genes in GBM1 and LN229 cells (Fig. 4a). Compared to $\mathrm{NADH}^{\text {high }} / \mathrm{CD} 133^{+}$and $\mathrm{NADH}^{\text {low }} / \mathrm{CD} 133^{-}$subpopulations, both $\mathrm{NADH}^{\text {high }} / \mathrm{CD} 133^{-}$and $\mathrm{NADH}^{\text {low }} /$ $\mathrm{CD}_{133^{+}}$subpopulations exhibited medium expression levels of those genes (Fig. 4a). Similar results were observed in the subpopulations which combined NADH and CD15 markers (Additional file 1: Figure S5A). Correspondingly, $\mathrm{NADH}^{\text {high }} / \mathrm{CD} 133^{+}$subpopulation had the highest ability of tumorsphere formation, $\mathrm{NADH}^{\text {low }}$ / $\mathrm{CD}_{133^{-}}$subpopulation had the lowest ability of tumorsphere formation, and $\mathrm{NADH}^{\text {high }} / \mathrm{CD} 133^{-}$and NADH${ }^{\text {low }} / \mathrm{CD}_{133^{+}}$subpopulations exhibited the medium ability of tumorsphere formation in GBM1 and LN229 cells (Fig. 4b). Besides, compared to the diameter, the average diameter of tumorspheres derived from $\mathrm{NADH}^{\text {high }}$ / $\mathrm{CD}_{133^{+}}, \mathrm{NADH}^{\text {high }} / \mathrm{CD} 133^{-}$, and $\mathrm{NADH}^{\text {low }} / \mathrm{CD} 133^{+}$ was markedly larger than that of $\mathrm{NADH}^{\text {low }} / \mathrm{CD} 133^{-}$-derived tumorspheres in GBM1214 and LN229 (Fig. 4c). The similar results were observed in the subpopulations which combined NADH and CD15 markers (Additional file 1: Figure S5B and C). Therefore, these results suggest that $\mathrm{NADH}^{\text {high }}$ subpopulation exhibits similar stemness traits with $\mathrm{CD} 133^{+}$and $\mathrm{CD} 15^{+}$subpopulations in vitro.

\section{The invasion ability and temozolomide resistance of $\mathrm{NADH}^{\text {high }}$ subpopulation are comparable with $\mathrm{CD}_{133^{+}}$ and $\mathrm{CD}_{15}{ }^{+}$subpopulations in glioma cells}

Previous studies have demonstrated that GSCs are implicated in tumor invasiveness and chemotherapeutic resistance $[33,34]$. Compared with $\mathrm{NADH}^{\text {low }}$ subpopulation, $\mathrm{NADH}^{\text {high }}$ subpopulation had higher invasive ability in LN229 and GBM1 cells ( $p<0.01$ for both) (Fig. 5a). The invasive abilities between $\mathrm{NADH}^{\text {high }}, \mathrm{CD}_{133^{+}}$, and $\mathrm{CD} 15^{+}$ subpopulations were comparable $(p<0.01)$ (Fig. $5 \mathrm{a}$ and Additional file 1: Figure S8). Moreover, NADH ${ }^{\text {high }}$ cells were less sensitive to TMZ than $\mathrm{NADH}^{\text {low }}$ cells (Fig. 5b). $\mathrm{CD}_{133^{+}}$and $\mathrm{CD} 15^{+}$cells were more resistant to TMZ than $\mathrm{CD} 133^{-}$and $\mathrm{CD} 15^{-}$cells (Fig. 5b), which were consistent with the previous reports [33, 35]. These results suggest that $\mathrm{NADH}^{\text {high }}$ subpopulation has similar malignant behaviors of invasion and chemotherapeutic resistance with $\mathrm{CD} 133^{+}$and $\mathrm{CD} 15^{+}$subpopulations.

\section{The intensity of NADH autofluorescence can be used as a biomarker to sort other CSCs}

In order to assess whether the intensity of NADH autofluorescence was suitable for isolating the CSCs in other tumors, we sorted NADH ${ }^{\text {high }}$ and $\mathrm{NADH}^{\text {low }}$ subpopulations from breast cancer cell line MDA-MB-231 and colorectal cancer cell line HT-29. With limiting dilution, we evaluated

Table 1 The percentage of $\mathrm{CD}_{133^{+}}$and $\mathrm{CD} 15^{+}$cells in $\mathrm{NADH} \mathrm{H}^{\text {high/low }}$ subpopulations of glioma cell lines

\begin{tabular}{|c|c|c|c|c|c|c|}
\hline \multirow{2}{*}{$\begin{array}{l}\text { Cell } \\
\text { lines }\end{array}$} & \multicolumn{3}{|c|}{ Percentage of $\mathrm{CD} 133^{+}$cells } & \multicolumn{3}{|c|}{ Percentage of $C D 15^{+}$cells } \\
\hline & Total & $\mathrm{NADH}^{\text {high }}$ & $\mathrm{NADH}^{\text {low }}$ & Total & $\mathrm{NADH}^{\text {high }}$ & $\mathrm{NADH}^{\text {low }}$ \\
\hline GBM1 & $0.73 \pm 0.04$ & $2.10 \pm 0.13$ & $0.60 \pm 0.13$ & $0.50 \pm 0.07$ & $2.47 \pm 0.44$ & $0.43 \pm 0.09$ \\
\hline GBM2 & $0.47 \pm 0.04$ & $2.63 \pm 0.24$ & $0.43 \pm 0.11$ & 0.1 & $0.40 \pm 0.13$ & 0 \\
\hline T98G & $1.37 \pm 0.22$ & $2.27 \pm 0.22$ & $0.63 \pm 0.31$ & $4.77 \pm 0.24$ & $6.40 \pm 0.07$ & $6.23 \pm 0.51$ \\
\hline LN229 & $0.53 \pm 0.04$ & $1.83 \pm 0.18$ & $0.80 \pm 0.13$ & $0.13 \pm 0.04$ & $0.67 \pm 0.04$ & $0.27 \pm 0.04$ \\
\hline
\end{tabular}




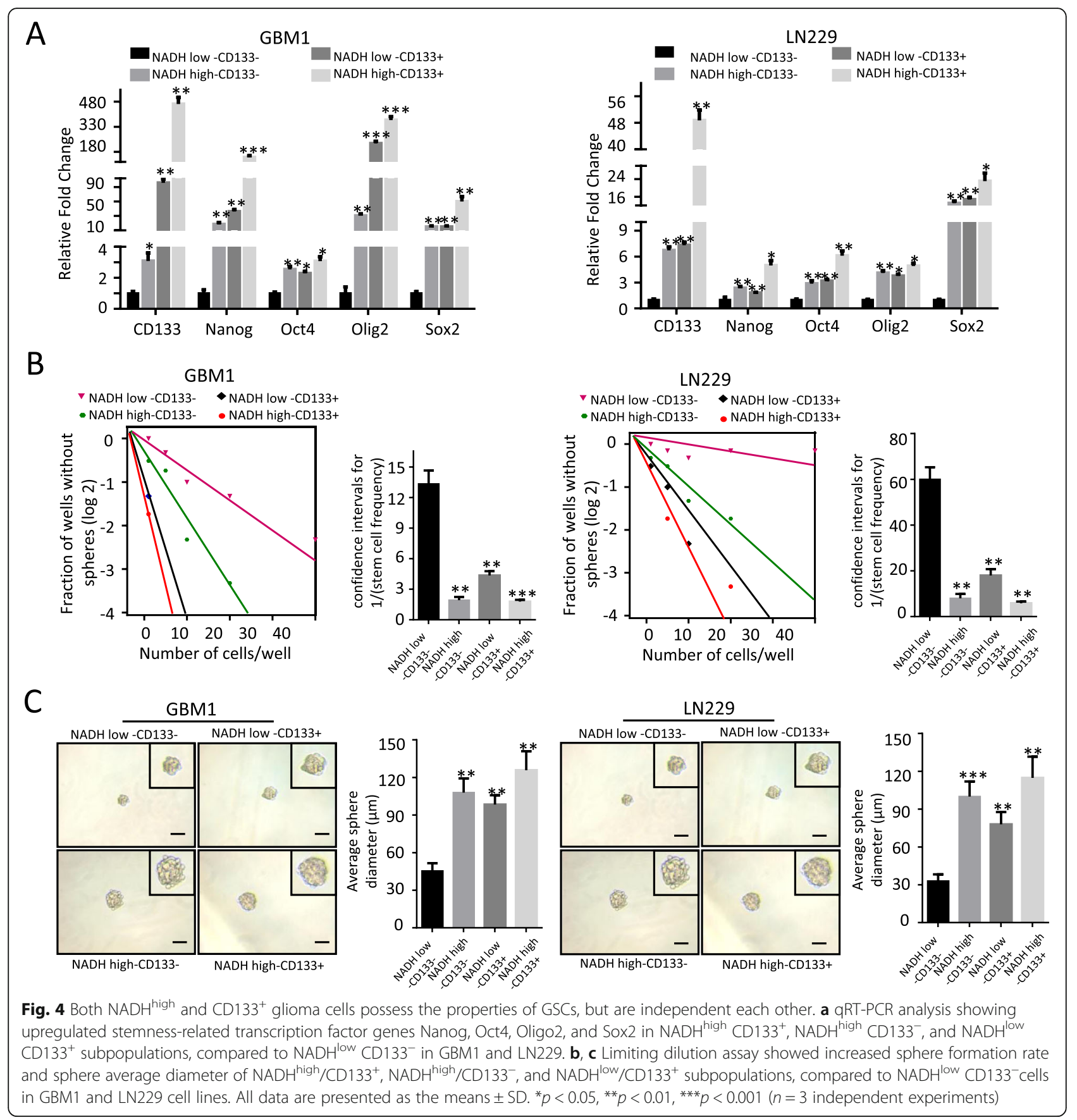

the self-renewal capability between $\mathrm{NADH}^{\text {high }} / \mathrm{ALDH}^{+}$, $\mathrm{NADH}^{\text {high }} / \mathrm{ALDH}^{-}, \mathrm{NADH}^{\text {low }} / \mathrm{ALDH}^{+}$, and $\mathrm{NADH}^{\text {low }} /$ $\mathrm{ALDH}^{-}$cells. Compared to NADH ${ }^{\mathrm{low}} / \mathrm{ALDH}^{-}$subpopulation, $\mathrm{NADH}^{\text {high }} / \mathrm{ALDH}^{+}, \mathrm{NADH}^{\text {high }} / \mathrm{ALDH}^{-}$, and NADH${ }^{\text {low }} / \mathrm{ALDH}^{+}$exhibited higher ability of tumorsphere formation both in MDA-MB-231 and HT-29 (Fig. 6a). Besides, the average diameter of the tumorspheres derived from $\mathrm{NADH}^{\text {high }} / \mathrm{ALDH}^{+}, \mathrm{NADH}^{\text {high }} / \mathrm{ALDH}^{-}$, and NADHlow $/ \mathrm{ALDH}^{+}$was larger than that from $\mathrm{NADH}^{\text {low }} / \mathrm{ALDH}^{-}$ both in MDA-MB-231 and HT-29 (Fig. 6b). Thus, the intensity of NADH autofluorescence could be used as a biomarker to isolate CSCs from breast cancer and colorectal cancer, implying that the intensity of NADH autofluorescence might be an extensive biomarker for CSCs.

\section{Discussion}

Many endogenous ingredients of cells and tissues, such as some amino acids, collagen, elastin, $\mathrm{NAD}(\mathrm{P}) \mathrm{H}$, flavin adenine dinucleotide (FAD), vitamins, lipids, and porphyrins, possess natural autofluorescence [36, 37]. Because these 

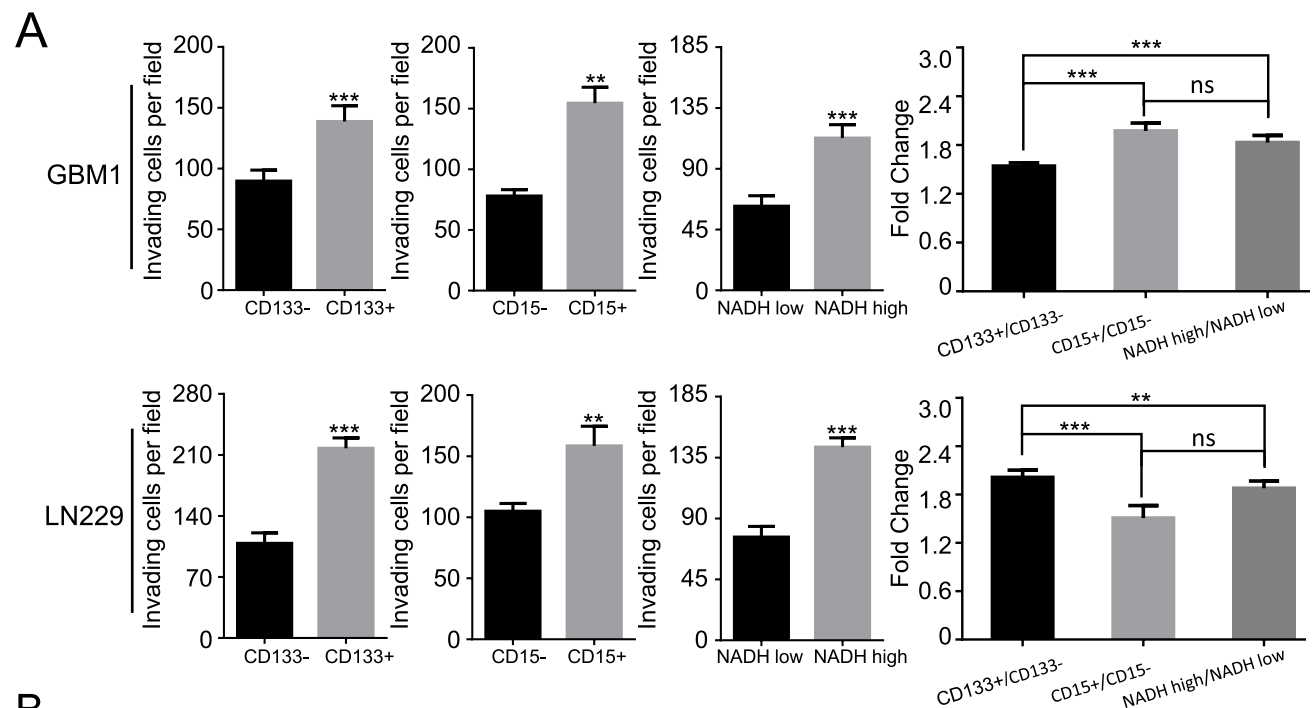

B
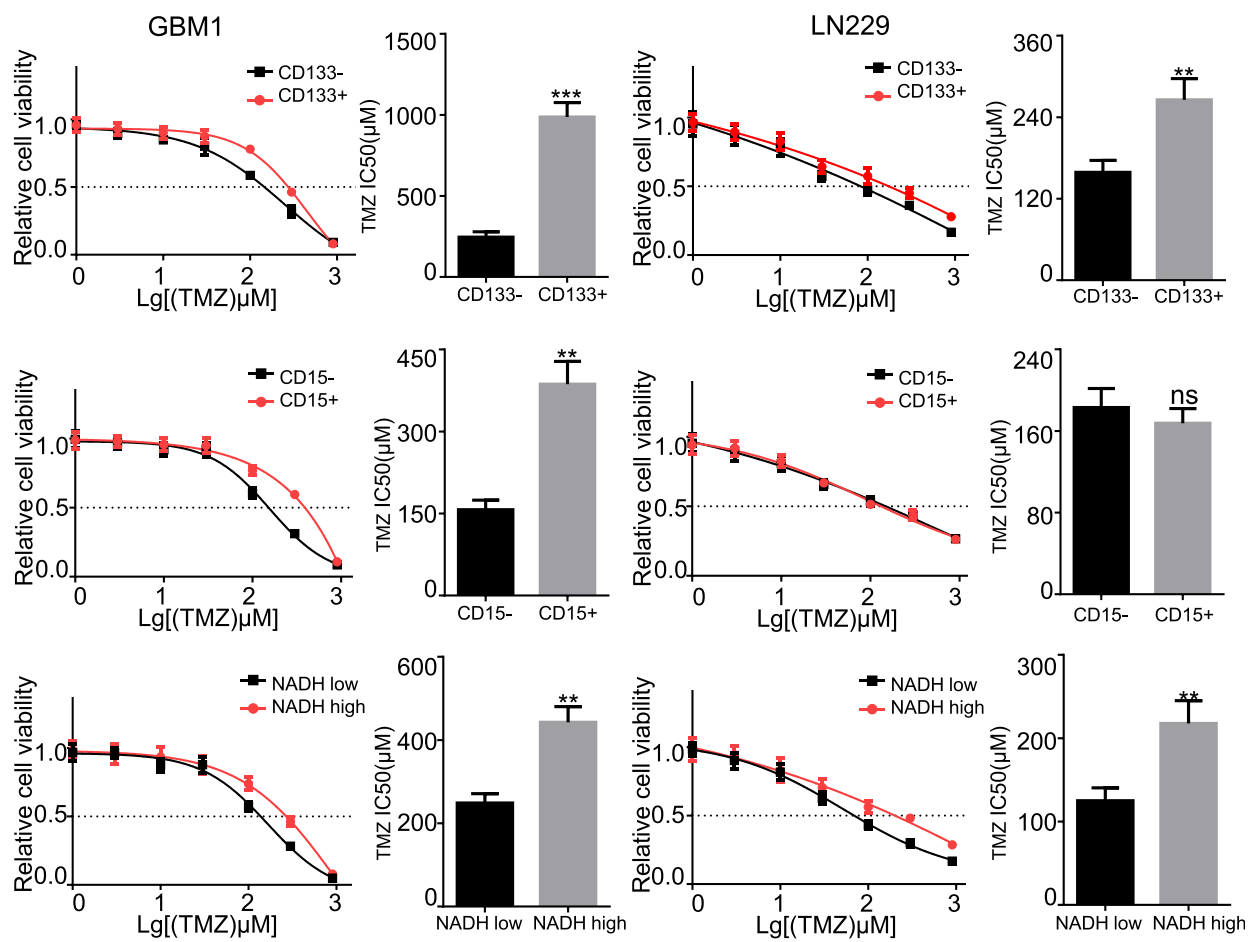

Fig. 5 The invasion ability and TMZ resistance of $\mathrm{NADH}^{\text {high }}$ glioma cells are similar to the ability of $\mathrm{CD} 133^{+}$and $\mathrm{CD} 15^{+}$subpopulation in glioma cells. a The quantitative histograms of invasion showed that invasion ability was significantly increased in NADH ${ }^{\text {high }}, \mathrm{CD}_{133^{+}}$, and $\mathrm{CD} 15^{+} \mathrm{LN} 229$ and GBM1 cells. $\mathbf{b}$ Effect of TMZ resistance in CD133, CD15, and NADH. IC50 of TMZ in CD133 ${ }^{+}$and $\mathrm{NADH}^{\text {high }}$ was higher than in CD133-, and $\mathrm{NADH}^{\text {low }}$ of GBM1 and LN229. The similar result was in CD15 of GBM1, but IC50 of TMZ in CD15 of LN229 was not different. All data are presented as the means \pm SD. ${ }^{* *} p<0.01,{ }^{* *} p<0.001$ ( $n=3$ independent experiments)

endogenous autofluorescence ingredients are the metabolites of cells or tissues, their autofluorescence intensity may directly reflect the physiological and/or pathological status of cells and tissues. So far, only the autofluorescence of $\mathrm{NAD}(\mathrm{P}) \mathrm{H}$ and FAD has been widely studied, mainly to be used in monitoring alteration of metabolic profiles and cellular oxidation-reduction status [38-40]. Moreover, the autofluorescence of $\mathrm{NAD}(\mathrm{P}) \mathrm{H}$ and FAD has been studied in normal stem cells and CSCs. Quinn et al. reported that the quantitative metabolic imaging using the endogenous fluorescence of NADH and FAD could monitor human mesenchymal stem cell differentiation into adipogenic and osteoblastic lineages [41]. Fluorescence of free and protein-bound NADH could discriminate different differentiation stages of neuronal progenitor stem cells [42]. Buschke et al. used multiphoton flow cytometry to non- 


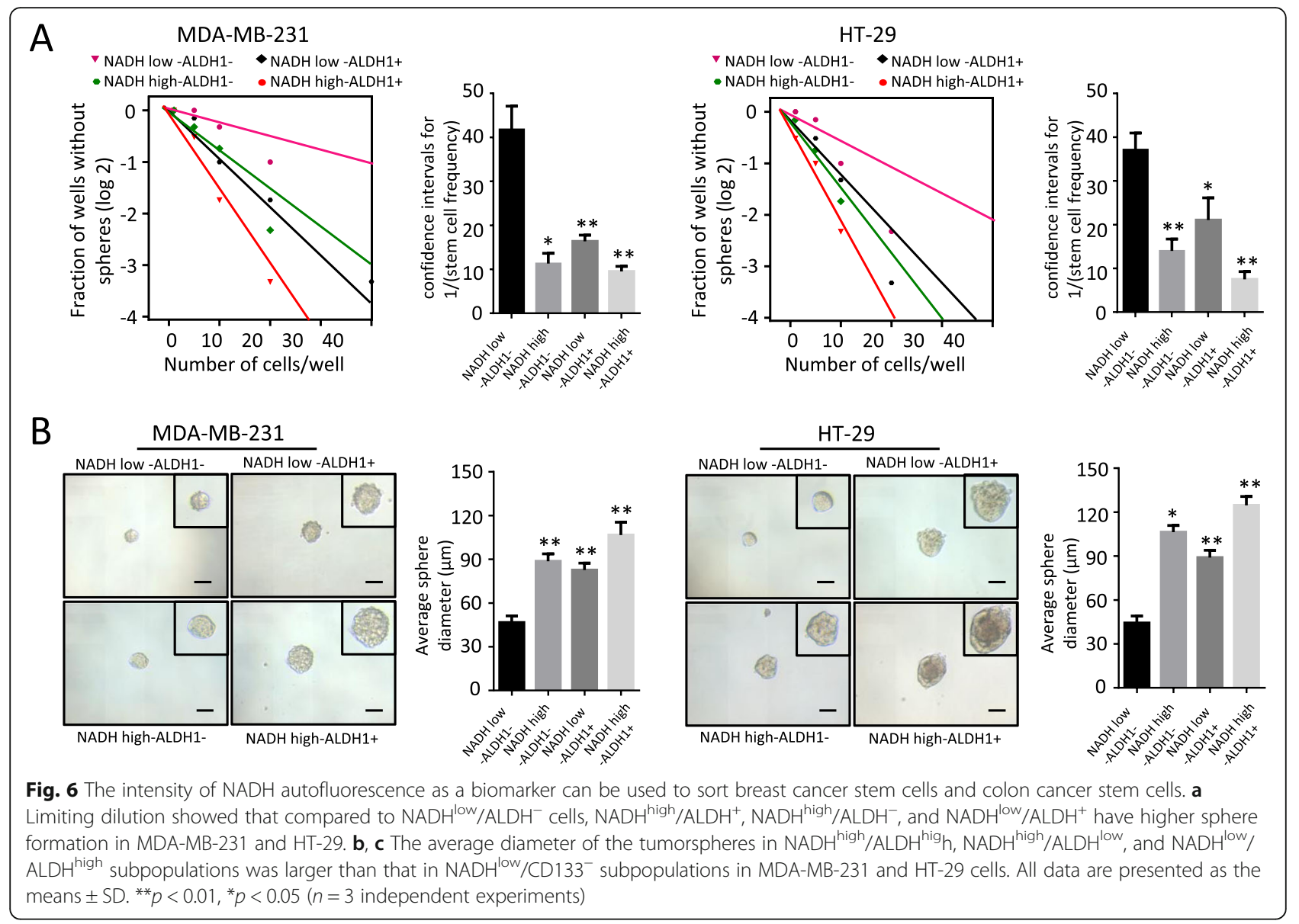

invasively characterize and purify populations of intact stem cell aggregates based on NADH intensity and assessed the differentiation capacity of sorted populations [43]. Bonuccelli et al. demonstrated that $\mathrm{NAD}(\mathrm{P}) \mathrm{H}$ autofluorescence was a new metabolic biomarker for CSCs in MCF-7 breast cancer cell line and sorted high NAD(P) H autofluorescence intensity cells exhibited CSC phenotype [26]. Miranda-Lorenzo et al. used FAD autofluorescence as a novel tool to isolate and characterize epithelial CSCs, but it had obvious limitations, such as exogenous riboflavin needed to be added to enhance the sensitivity, and the experimental results varied with the concentrations of riboflavin, incubation times, and cell concentrations [44]. Therefore, in comparison with FAD, NADH autofluorescence is a more reliable and promising biomarker to be used to sort CSCs without exogenous substances to be added. In the present study, we sorted NADH ${ }^{\text {high }}$ subpopulation from glioma cells and further demonstrated that this subpopulation possessed the properties of CSCs, featured with significant increase of stemness-related gene expression, tumorsphere formation, invasiveness, resistance to TMZ in vitro, and tumorigenicity in vivo.

Herein, we used a wavelength of $355 \mathrm{~nm}$ or $375 \mathrm{~nm}$ for the autofluorescence of NADH. However, under our experimental conditions, the sorted NADH ${ }^{\text {high }}$ subpopulation actually also contained $\mathrm{NADPH}^{\text {high }}$ cells because $\mathrm{NADH}$ and NADPH are spectrally identical. Nevertheless, despite the two co-enzymes exert different functions with NAD/NADH as a key determinant of cellular energy metabolism and NADP/NADPH as a central role in biosynthetic pathways and antioxidant defense, both of them may be important for stemness maintenance of CSCs. Several other studies have suggested that the concentration of NADH is higher (up to 5 times) than the $\mathrm{NADPH}$ in mammalian and the quantum yield of $\mathrm{NADH}$ is 1.25 to 2.5 times higher than that of NADPH [45]. Since NADH is the main source of the autofluorescence, we used NADH ${ }^{\text {high }}$ but not $\mathrm{NAD}(\mathrm{P}) \mathrm{H}^{\text {high }}$ subpopulation as GSCs.

CD133 and CD15 have been regarded as reliable maker for enriching GSCs. In our studies, we compared the relationship of $\mathrm{CD}_{133^{+}}, \mathrm{CD}_{1} 5^{+}$, and $\mathrm{NADH}^{\text {high }}$ subpopulations and found that $\mathrm{CD} 133 / \mathrm{CD} 15$ defines distinct cell subpopulations and both $\mathrm{CD} 133^{+}$and $\mathrm{CD} 15^{+}$ cells were only partially overlapped with $\mathrm{NADH}^{\text {high }}$ subpopulation in glioma cells. Thus, $\mathrm{NADH}^{\text {high }}$ may define a subset of GSCs independent of $\mathrm{CD} 133^{+}$and $\mathrm{CD} 15^{+}$ subsets. As for the relationship between $\mathrm{CD}_{133^{+}}$and 
$\mathrm{CD} 5^{+}$cells, Son et al. reported that most $\mathrm{CD} 133^{+}$ tumor cells freshly isolated from glioma specimens were $\mathrm{CD}_{15}{ }^{+}$[6], but a less overlap between $\mathrm{CD} 133^{+}$and $\mathrm{CD}_{1} 5^{+}$subsets was observed in GBM1 and LN229 cells (Additional file 1: Figures S6 and S7).

As a basic metabolite, NADH is ubiquitously distributed in cells. Therefore, NADH autofluorescence could be a biomarker not only for GSCs, but also for other CSCs. Indeed, we found that $\mathrm{NADH}^{\text {high }} / \mathrm{ALDH}^{+}$, $\mathrm{NADH}^{\text {high }} / \mathrm{ALDH}^{-}$, and $\mathrm{NADH}^{\text {low }} / \mathrm{ALDH}^{+}$subpopulations had higher self-renewal ability than $\mathrm{NADH}^{\text {low }}$ / $\mathrm{ALDH}^{-}$subpopulation in breast cancer and colon cancer cells, implying that the autofluorescence of $\mathrm{NADH}$ might serve as a biomarker for CSCs of these cancers.

\section{Conclusion}

Our findings demonstrate that intracellular autofluorescence of NADH is a non-labeling, sensitive maker for isolating GSCs, even for other CSCs.

\section{Supplementary information}

Supplementary information accompanies this paper at https://doi.org/10. 1186/s13287-019-1467-7.

\begin{abstract}
Additional file 1: Table S1. The clinical features of the glioma specimens used in this study, Table S2. Primers used for aRT-PCR analyses in this study. Table S3. Tumor formation rates of xenograft implanted with different cell number of NADH high and NADH low LN229 cells. Figure S1. Intensity of NADH autofluorescence in different WHO grade glioma tissues detected by FACS. Figure S2. Representative images of flow cytometry analysis for proportion of CD133+ cells in NADHhigh and $\mathrm{NADH}^{\text {low }}$ subpopulations in glioma cells. Figure S3.

Representative images of flow cytometry analysis for proportion of $\mathrm{CD} 15+$ cells in $\mathrm{NADH}^{\text {high }}$ and $\mathrm{NADH}^{\text {low }}$ subpopulations in glioma cells. Figure S4. The representative flow cytometry images of the percentage of $\mathrm{NADH}^{\text {high }}$ cells in CD133+/CD15+ populations. Figure S5. Both NADHhigh and CD15+ giloma cells possess the properties of CSCs, but are partially overlapped. Figure S6. The representative flow cytometry images of the relationship between $\mathrm{CD} 133^{+}, \mathrm{CD}_{1} 5^{+}$and $\mathrm{NADH}^{\text {high }}$ populations. Figure S7. The representative flow cytometry images of the relationship between $\mathrm{CD} 133^{+}, \mathrm{CD}_{15} 5^{+}$and $\mathrm{NADH}^{\text {high }}$ populations. Figure S8. The representative images of invasion assay for $\mathrm{NADH}^{\text {high }}$ and $\mathrm{NADH}^{\text {low }}$ CD $133^{+/-}$and $\mathrm{CD} 15^{+/}$subpopulations in GBM1 and LN229 cell lines. Compared to CD133-, CD15- NADH ${ }^{\text {low }}$ subsets, CD133 ${ }^{+}, \mathrm{CD} 15^{+}$and $\mathrm{NADH}^{\text {high }}$ cells exhibited stronger invasive ability in GBM1 and LN229 cell lines.
\end{abstract}

\section{Abbreviations}

ALDH: Aldehyde dehydrogenase; bFGF: Basic fibroblast growth factor; CSCs: Cancer stem cells; EGF: Epidermal growth factor; FACS: Fluorescenceactivated cell sorting; FAD: Flavin adenine dinucleotide; FLIM: Fluorescence lifetime microscopy; GSCs: Glioma stem cells; NADH: Nicotinamide adenine dinucleotide; TMZ: Temozolomide; WHO: World Health Organization

\section{Acknowledgements}

We would like to thank the specimen bank of Southwest Hospital for the specimens.

\section{Authors' contributions}

$Y C, X B$, and $Q M$ contributed to the study conception and design. $Y C, X B$, and $\mathrm{QM}$ contributed to the development of methodology. YY, YZ, JM, RC, and MZ contributed to the acquisition of data. QM, YY, YW, and LW contributed to the analysis and interpretation of data. WD, DW, and DX were involved in the administrative, technical, or material support. QM, YW, PZ, YC, and XB contributed to the writing, review, and/or revision of the manuscript. $Y C$ and $\mathrm{XB}$ were involved in the study supervision. All authors read and approved the final manuscript.

\section{Funding}

This work was supported by grants from the National Natural Science Foundation of China (innovative research group projects, 81821003 to XW Bian), Chongqing Science and Technology Commission (cstc2017jcyjA0544 to QH Ma), and Southwest Hospital Foundation (SWH2016JCZD-09 to DY Guo).

Availability of data and materials

For data requests, please contact the authors.

Ethics approval and consent to participate

This study was approved by the Ethical/Scientific Committee of Southwest Hospital.

Consent for publication

Not applicable

\section{Competing interests}

The authors declare that they have no competing interests.

Received: 17 July 2019 Revised: 14 October 2019

Accepted: 22 October 2019 Published online: 20 November 2019

\section{References}

1. Singh SK, Hawkins C, Clarke ID, Squire JA, Bayani J, Hide T, et al. Identification of human brain tumour initiating cells. Nature. 2004;432:396401.

2. Minata M, Audia A, Shi J, Lu S, Bernstock J, Pavlyukov MS, et al. Phenotypic plasticity of invasive edge glioma stem-like cells in response to ionizing radiation. Cell Rep. 2019:26:1893-905.

3. Liu G, Yuan X, Zeng Z, Tunici P, Ng H, Abdulkadir IR, et al. Analysis of gene expression and chemoresistance of CD133+ cancer stem cells in glioblastoma. Mol Cancer. 2006;5:67.

4. Hattermann K, Fluh C, Engel D, Mehdorn HM, Synowitz M, Mentlein R, et al. Stem cell markers in glioma progression and recurrence. Int J Oncol. 2016; 49:1899-910.

5. Singh SK, Clarke ID, Terasaki M, Bonn VE, Hawkins C, Squire J, et al. Identification of a cancer stem cell in human brain tumors. Cancer Res. 2003;63:5821-8.

6. Son MJ, Woolard K, Nam DH, Lee J, Fine HA. SSEA-1 is an enrichment marker for tumor-initiating cells in human glioblastoma. Cell Stem Cell. 2009;4:440-52.

7. Wang J, Sakariassen PO, Tsinkalovsky O, Immervoll H, Boe SO, Svendsen A, et al. CD133 negative glioma cells form tumors in nude rats and give rise to CD133 positive cells. Int J Cancer. 2008;122:761-8.

8. Beier D, Hau P, Proescholdt M, Lohmeier A, Wischhusen J, Oefner PJ, et al. CD133(+) and CD133(-) glioblastoma-derived cancer stem cells show differential growth characteristics and molecular profiles. Cancer Res. 2007; 67:4010-5.

9. Panchision DM, Chen HL, Pistollato F, Papini D, Ni HT, Hawley TS. Optimized flow cytometric analysis of central nervous system tissue reveals novel functional relationships among cells expressing CD133, CD15, and CD24. Stem Cells. 2007;25:1560-70.

10. Barteneva NS, Ketman K, Fasler-Kan E, Potashnikova D, Vorobjev IA. Cell sorting in cancer research--diminishing degree of cell heterogeneity. Biochim Biophys Acta. 1836;2013:105-22.

11. Teslaa T, Teitell MA. Pluripotent stem cell energy metabolism: an update. EMBO J. 2015;34:138-53.

12. Shen YA, Wang CY, Hsieh YT, Chen YJ, Wei YH. Metabolic reprogramming orchestrates cancer stem cell properties in nasopharyngeal carcinoma. Cell Cycle. 2015:14:86-98.

13. Blacker TS, Mann ZF, Gale JE, Ziegler M, Bain AJ, Szabadkai G, et al. Separating NADH and NADPH fluorescence in live cells and tissues using FLIM. Nat Commun. 2014;5:3936. 
14. Chance B, Schoener B, Oshino R, Itshak F, Nakase Y. Oxidation-reduction ratio studies of mitochondria in freeze-trapped samples. $\mathrm{NADH}$ and flavoprotein fluorescence signals. J Biol Chem. 1979;254:4764-71.

15. Heikal AA. Intracellular coenzymes as natural biomarkers for metabolic activities and mitochondrial anomalies. Biomark Med. 2010;4:241-63.

16. Zipfel WR, Williams RM, Christie R, Nikitin AY, Hyman BT, Webb WW. Live tissue intrinsic emission microscopy using multiphoton-excited native fluorescence and second harmonic generation. Proc Natl Acad Sci U S A. 2003;100:7075-80

17. Guo HW, Chen CT, Wei YH, Lee OK, Gukassyan V, Kao FJ, et al. Reduced nicotinamide adenine dinucleotide fluorescence lifetime separates human mesenchymal stem cells from differentiated progenies. J Biomed Opt. 2008; 13:50505.

18. Konig K, Uchugonova A, Gorjup E. Multiphoton fluorescence lifetime imaging of 3D-stem cell spheroids during differentiation. Microsc Res Tech. 2011;74:9-17.

19. Stringari $C$, Cinquin A, Cinquin O, Digman MA, Donovan PJ, Gratton E. Phasor approach to fluorescence lifetime microscopy distinguishes different metabolic states of germ cells in a live tissue. Proc Natl Acad Sci U S A. 2011;108:13582-7.

20. Trinh AL, Chen $H$, Chen Y, Hu Y, Li Z, Siegel ER, et al. Tracking functional tumor cell subpopulations of malignant glioma by phasor fluorescence lifetime imaging microscopy of NADH. Cancers (Basel). 2017;9:1-13

21. Li Z, Bao S, Wu Q, Wang H, Eyler C, Sathornsumetee S, et al. Hypoxiainducible factors regulate tumorigenic capacity of glioma stem cells. Cancer Cell. 2009;15:501-13.

22. Guryanova OA, Wu Q, Cheng L, Lathia JD, Huang Z, Yang J, et al. Nonreceptor tyrosine kinase BMX maintains self-renewal and tumorigenic potential of glioblastoma stem cells by activating STAT3. Cancer Cell. 2011; 19:498-511.

23. Chen $Q$, Weng HY, Tang XP, Lin Y, Yuan Y, Li Q, et al. ARL 4 C stabilized by AKT/mTOR pathway promotes the invasion of PTEN-deficient primary human glioblastoma. J Pathol. 2019;247:266-78.

24. Ji C, Yang L, Yi W, Xiang D, Wang Y, Zhou Z, et al. Capillary morphogenesis gene 2 maintains gastric cancer stem-like cell phenotype by activating a Wnt/beta-catenin pathway. Oncogene. 2018;37:3953-66.

25. Song K, Yuan Y, Lin Y, Wang YX, Zhou J, Gai QJ, et al. ERBB3, IGF1R, and TGFBR2 expression correlate with PDGFR expression in glioblastoma and participate in PDGFR inhibitor resistance of glioblastoma cells. Am J Cancer Res. 2018;8:792-809.

26. Bonuccelli G, De Francesco EM, de Boer R, Tanowitz HB, Lisanti MP. NADH autofluorescence, a new metabolic biomarker for cancer stem cells: identification of vitamin C and CAPE as natural products targeting "stemness". Oncotarget. 2017:8:20667-78.

27. Itoh H, Nishikawa S, Haraguchi T, Arikawa Y, Hiyama M, Iseri T, et al. Identification of rhodamine 123-positive stem cell subpopulations in canine hepatocellular carcinoma cells. Biomed Rep. 2017;7:73-8.

28. Lee J, Kotliarova S, Kotliarov Y, Li A, Su Q, Donin NM, et al. Tumor stem cells derived from glioblastomas cultured in bFGF and EGF more closely mirror the phenotype and genotype of primary tumors than do serum-cultured cell lines. Cancer Cell. 2006;9:391-403.

29. Galli R, Binda E, Orfanelli U, Cipelletti B, Gritti A, De Vitis S, et al. Isolation and characterization of tumorigenic, stem-like neural precursors from human glioblastoma. Cancer Res. 2004;64:7011-21.

30. Di K, Linskey ME, Bota DA. TRIM11 is overexpressed in high-grade gliomas and promotes proliferation, invasion, migration and glial tumor growth. Oncogene. 2013;32:5038-47.

31. Jin X, Jin X, Jung JE, Beck S, Kim H. Cell surface Nestin is a biomarker for glioma stem cells. Biochem Biophys Res Commun. 2013;433:496-501.

32. Raychaudhuri B, Rayman P, Huang P, Grabowski M, Hambardzumyan D, Finke $\mathrm{JH}$, et al. Myeloid derived suppressor cell infiltration of murine and human gliomas is associated with reduction of tumor infiltrating lymphocytes. J Neuro-Oncol. 2015;122:293-301.

33. Munoz JL, Rodriguez-Cruz V, Rameshwar P. High expression of miR-9 in CD133(+) glioblastoma cells in chemoresistance to temozolomide. J Cancer Stem Cell Res. 2015;3:1-14

34. Hu B, Wang Q, Wang YA, Hua S, Sauve CG, Ong D, et al. Epigenetic activation of WNT5A drives glioblastoma stem cell differentiation and invasive growth. Cell. 2016;167:1281-95.

35. William D, Walther M, Schneider B, Linnebacher M, Classen CF. Temozolomide-induced increase of tumorigenicity can be diminished by targeting of mitochondria in in vitro models of patient individual glioblastoma. PLoS One. 2018;13:e191511.

36. Croce AC, Bottiroli G. Autofluorescence spectroscopy and imaging: a tool for biomedical research and diagnosis. Eur J Histochem. 2014;58:2461.

37. Billinton N, Knight AW. Seeing the wood through the trees: a review of techniques for distinguishing green fluorescent protein from endogenous autofluorescence. Anal Biochem. 2001;291:175-97.

38. Jones JD, Ramser HE, Woessner AE, Quinn KP. In vivo multiphoton microscopy detects longitudinal metabolic changes associated with delayed skin wound healing. Commun Biol. 2018;1:198.

39. Smelt MJ, Faas MM, de Haan BJ, de Vos P. Pancreatic beta-cell purification by altering FAD and NAD(P) H metabolism. Exp Diabetes Res. 2008;2008: 165360.

40. Skala MC, Riching KM, Gendron-Fitzpatrick A, Eickhoff J, Eliceiri KW, White $J G$, et al. In vivo multiphoton microscopy of NADH and FAD redox states, fluorescence lifetimes, and cellular morphology in precancerous epithelia. Proc Natl Acad Sci U S A. 2007;104:19494-9.

41. Quinn KP, Sridharan GV, Hayden RS, Kaplan DL, Lee K, Georgakoudi I. Quantitative metabolic imaging using endogenous fluorescence to detect stem cell differentiation. Sci Rep. 2013;3:3432.

42. Stringari C, Nourse JL, Flanagan LA, Gratton E. Phasor fluorescence lifetime microscopy of free and protein-bound NADH reveals neural stem cell differentiation potential. PLoS One. 2012;7:e48014.

43. Buschke DG, Squirrell JM, Vivekanandan A, Rueden CT, Eliceiri KW, Ogle BM. Noninvasive sorting of stem cell aggregates based on intrinsic markers. Cytometry A. 2014:85:353-8.

44. Miranda-Lorenzo I, Dorado J, Lonardo E, Alcala S, Serrano AG, ClausellTormos J, et al. Intracellular autofluorescence: a biomarker for epithelial cancer stem cells. Nat Methods. 2014;11:1161-9.

45. Vishwasrao HD, Heikal AA, Kasischke KA, Webb WW. Conformational dependence of intracellular NADH on metabolic state revealed by associated fluorescence anisotropy. J Biol Chem. 2005;280:25119-26.

\section{Publisher's Note}

Springer Nature remains neutral with regard to jurisdictional claims in published maps and institutional affiliations.

Ready to submit your research? Choose BMC and benefit from:

- fast, convenient online submission

- thorough peer review by experienced researchers in your field

- rapid publication on acceptance

- support for research data, including large and complex data types

- gold Open Access which fosters wider collaboration and increased citations

- maximum visibility for your research: over $100 \mathrm{M}$ website views per year

At $\mathrm{BMC}$, research is always in progress.

Learn more biomedcentral.com/submissions 